\title{
Unpublished Roman Terracotta Oil Lamps in Matrouh Archaeological Museum
}

\author{
Wessam Fekry Ibrahim Moussa \\ Lecturer, Faculty of Tourism and Hotels, Matrouh University, Egypt
}

\begin{abstract}
:
In daily life of antiquity, the prevalence of terracotta oil lamps makes them a fascinating artifact of study, whether as a representation of individual preferences, religious ritual, popular trends or evidence of commercial trade patterns. Matrouh Archaeological Museum acquires ten interesting Roman oil lamps, which are unpublished before and studied in this paper for the first time. They were collected from the stores of several museums around Egypt such as Suez National Museum, Graeco-Roman Museum of Alexandria, Ismailia Museum and from Saqqara and seemed to be produced in the usual pottery workshops of Graeco-Roman Egypt. As it is common in the field of archeology, they are neither identified nor dated precisely. Since the lamps' typology is a sign of local pottery production, careful investigations may determine the provenance and chronology. The study also presents a carful description of each object enhanced by its registration number, material and dimensions, along with photographs from different angles to document lamps' main details digitally. The museum and its visitors can contribute from the study results as well
\end{abstract}

as specialists in the fields of Graeco-Roman archeology.

Keywords: Oil Lamps, Graeco-Roman Era, Museums Collections, Graeco-Roman archeology.

\section{Introduction:}

Since the dawn of the mankind, men attempted to create light and chase away the darkness. In that effort, people took a long way. Biological and archaeological evidence proved that circa 400,000 and 800,000 years ago man invented and developed some tools

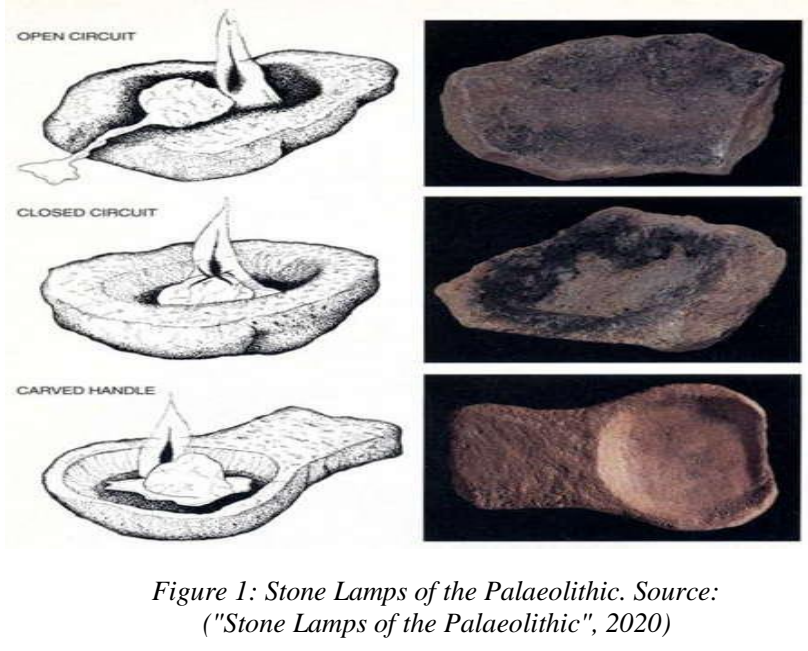

to control fire and its power such as hearths and torches. One of the earliest solutions, 
which were used for lightening, was the oil lamp (De Rosa, 2015). Primitive versions of lamps were invented by early man, during the Paleolithic period, he used hollow stones (fig. 1), shells, or any nonflammable material as a container with wicks made of any fibrous material soaked in either oil or animal fat which they would be ignited to produce flame (Bailey, 1975). The materials used to make oil lamps, as well as their fuel, evolved over time mas industry and technology progressed. In research from Sindh Exploration and Adventurer Society (2001), the first artificial oil lamps were discovered in Egypt, Greece, and Rome, and could be regarded the first mass produced artifacts in history. They were made of various materials, including clay, bronze, stone, and alabaster and shaped like a saucer with a hole for a floating wick. They were reusable and more secure to be carried than torches.

Robbins stated that despite the fact that undoubted lamps from the dynastic period are almost entirely absent from known finds, there are evidences for their existence (Robbins, 1939). According to classical written sources, the Egyptians used mostly simple lamps in the form of shallow small bowls with wicks made from castor plant fibers, linen cloth or reeds not only to illuminate their homes, but also in religious rituals, which were an integral part of the ancient Egyptians daily life during those days. For example, the historian Herodotus, $5^{\text {th }}$ century B.C, witnessed the Egyptian lighting and wrote about a Festival known as the "Festival of Lamp Lighting" at Sais (Herodotus, Book II.62), during such celebration the entire city would light oil lamps which were left burning all night around houses, he said:

"At the times when they gather together at the city of Saisfor their sacrifices, on a certain night they all kindle lamps many in number in the open-air round about the houses; now the lamps are saucers full of salt and oil mixed, and the wick floats by itself on the surface, and this burns during the whole night;" (Herodotus, Book II.62).

Herodotus' text reflects the technique of the Egyptian lamp, which despite its simplicity, was able to remain lit throughout the night. It seems also that the salt was used to support the wick on top and prevent the oil

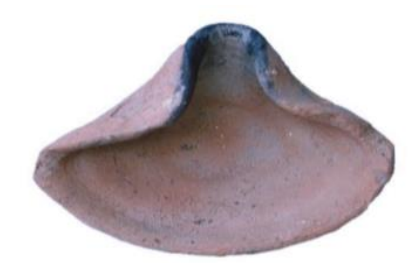

Figure 2: Egyptian floating wick saucer lamp "Cocked hat”. c. 300-200 B.C. source: Thomas, 2013, figure 1.

from spilling readily.

Besides, Clement of Alexandria attributed the invention of lamps to the Egyptians. Based on Herodotus and Clement of Alexandria, Robins concluded that the lack of examples is explained by the Egyptian use of the floatingwick lamp which, as he stated,"(a) preceded the rounded spout forms and (b) originated in Egypt before finding its way to Greece" (Robbins, 1939). Bogucki admitted too that Egypt was known and credited with the invention of oil lamps (Bogucki, 2008). With the fact that excavations have not introduced certain artificial lamps examples of early date in Egypt, clay lamps, however, have been found among the remains of the Minoan civilization in Crete. Stone lamps occurred too on the Acropolis of Mycenae (Walters, 1914).

\section{Objectives of the Study:}

Oil lamps are widely found at archaeological sites either locally or across the Mediterranean region. They played a vital role in the daily 
life of many cultures. Essentially, they were a source of portable artificial light, much like a candle or recent flashlight. They were also critical in sacred rituals. They were given as votive offerings, used frequently in ceremonies, or set-in burial chambers. The studying of 10 oil lamps in Matrouh Archaeological Museum aims to:

- Give a good sense of the common lamp types that produced in Egypt under the Roman Empire.

- Present a good description and documentation of those lamps.

\section{Literature Review:}

Bartoli \& Bellori, presented an illustrated work, as early as the $17^{\text {th }}$ century A.D, on clay Roman oil lamps discovered in ancient Roman catacombs (Bartoli \& Bellori, 1691). Until now these objects are being studied, this is mainly due to their large amount finds, inherent aesthetic value, affordability and ease of transport. Most of publications on ceramic lamps are traditionally in the form of catalogues and focus on determining lamps' typology, chronology and significance to art-history (De Rosa, 2015). Examples of these catalogues are Richard Howland's (Howland, 1958) typology and catalogue of lamps from the Athenian Agora, Ingeborg Scheibler's (Scheibler, 1976) typology and catalogue of the lamps from the Athenian Kerameikos, Anne Bovon's (Bovon, 1966) catalogue of lamps from Argos, and Francine Blondé's (Blondé, 1983) typology and catalogue of the lamps from Thorikos. Within the previous literatures, lamps are described according to their type or classification, dependent upon both their form and decoration. In contrast, both of Loeschcke and Bailey undertake deeply the study of Roman lamps. Loeschcke's study (Loeschcke, 1919) was around 1100 lamps found at the site of Vindonissa, an important Roman legionary camp, at modern Windisch, Switzerland. He divided lamps into fourteen types. On the other hand, Bailey (Baily, 1975) focuses on the Roman lamps which are part of the British Museum's collection, including Roman lamps found in Italy and the provinces that were part of the Roman Empire. Loeschcke and Bailey established typologies which allow a specific lamp to be dated based on its characteristics such as the decoration, size and shape of the nozzle, discus, and shoulder form. However, Loeschcke's typology became and still the widest used typology for the dating and classification of Roman Empire period lamps. This is mainly due to datable examples of lamps, making the work a reliable, systematic set of classifications and chronology. So, this research takes Loeschcke's study of the very large assemblage of lamps as a base for the classification of Matrouh Museum lamps.

\section{The Manufacture of Oil Lamps:}

Different methods were used to manufacture this kind of ceramic vessels including handmade modeling, throwing on the wheel and more developed kinds were casted by molds. This innovation became the dominant method of manufacture for the next thousand years.

The first two techniques were used within the Levant, Asia Minor, Crete and Cyprus from the 3rd millennium B.C and throughout the Mediterranean Bronze Age (Bailey, 1975). Lamps of such forms consisted of an open shallow vessel, with a folded wick rest created from the rim (Robins, 1939). It was not until the 7th century B.C in Greece that more sophisticated forms of wheel-made lamps were developed and soon prevailing. At the beginning, they took the shape of a saucer with one pinched corner forming a single wick-rest or spout. Later on, sometimes, more 
spouts were added (Bussière, \& Wohl, 2017). The pinched nozzle was a technique that aided in holding the wick and preventing the wick from sinking or burning up in addition to the focusing of light advancement. Lamps of such type with folded rims are often referred to as "cocked-hat" lamps (fig. 2) (Walters, 1914).

By the mid of the $7^{\text {th }}$ century lamps with bridged nozzles showed up and pushed out their unbridged counterparts the following century and a half. Howland (Howland ,1958) and then Bailey (Bailey,1975) argue that the bridged form was nearly invented by Greeks in western Asia Minor. It seems that from the $7^{\text {th }}$ to the $3^{\text {rd }}$ centuries B.C, Greek wheel-made clay lamps became more enclosed where the rim of the vessel extended over the dish of the lamp. Nozzles were also formed separately and then attached to the body. These changes assisted in controlling the flame as well as reducing the amount of oil lost (De Rosa, 2015).

The common trend over time was towards an increasingly profound body to realize more prominent oil capacity, a progressively broadened rim or shoulder to deliver a more closed shape in order to minimize spillage, and a longer nozzle for expanded separation of the fuel from the fire flame.

With the beginning of the $3^{\text {rd }}$ century B.C, the first mold-made lamps appeared and started to compete with wheel-made lamps (Bussière, \& Wohl, 2017). Wheel made lamps continued to be produced alongside the mold made for around three hundred years, but soon molds revolutionized the lamp industry. Moreover, it remained the standard method for lamps production through the end of antiquity and beyond (Howland 1958). The implementation of two-piece plaster or ceramic molds allowed for the mass production of cheaper and more durable lamps than wheel-made ones (Howland, 1958). Hellenistic lamps, between the $3^{\text {rd }}$ to $1^{\text {st }}$ centuries B.C, were produced primarily in Asia Minor and Egypt. According to Walter, the oldest forms have a long narrow nozzle, no handle at the back but with a side-handle ornamented with volutes (Walters, 1914). Walter in his catalogue (Walters, 1914) presented an early example of a lamp-mold from Naukratis, which goes back to about the $2^{\text {nd }}$ century B.C., it was for the upper part of a lamp of 'delphiniform' (fig. 3).

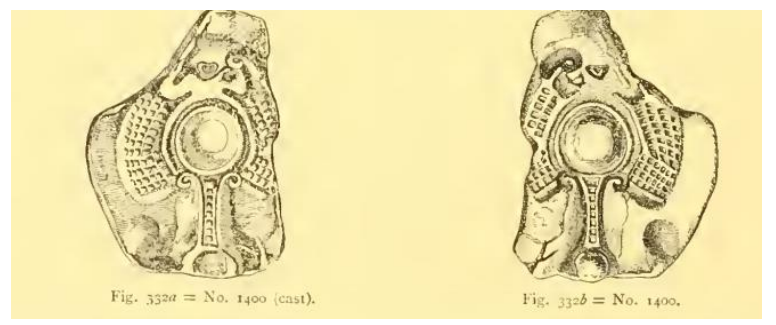

Figure 3: Mold for upper part of lamp of delphiniform type. From Naukratis. Usual coarse red brick-like clay of Naukratis. Walter, 1914 fig. 332, No 1400

\section{The Use of Lamps During the Antiquities:}

The use of oil lamps for the production of artificial light was extremely prevalent in the Mediterranean throughout antiquity. They made night-time activities possible, including a variety of craftwork, writing, or even leisure activities, that could not take place in darkness. They reflect a somewhat different type of artificial light, being more compact and, if used in several ways, more portable than the domestic hearth. Walters summarized the purposes for which lamps were used by the Romans under three main heads: illumination in private houses, in public buildings, or on occasions of rejoicing; as offerings in temples; and as funerary furniture (Walters, 1914).

\section{Principal Parts of A Lamp:}

Most oil lamps can be understood as having the major following parts (fig. 4) (Walters, 1914): 
a) the body or reservoir, usually circular or oval, serves as a container for the oil (fuel);

b) the discus, flat circular top, on which the design, if any, is placed, sometimes with an ornamented rim (margo) c); d) the nozzle/s, with a hole for inserting the wick (ellychnium); e) the handle (manubrium). Earlier versions of lamps were usually opened, but in the closed Roman lamps, there are usually a small filling-hole for pouring the oil. Sometimes there is a second smaller hole, according to Walters, it was either for air or for the insertion of a kind of needle used to change the wick (Walters, 1914).

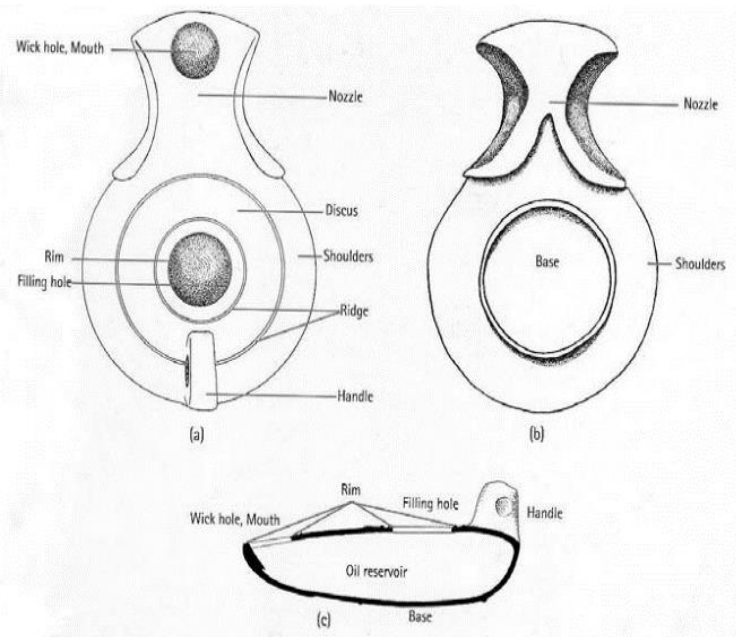

Figure 4: Oil Lamp Features. Source: (Westenholz, 2004).

\section{The Study Sample:}

This study comprises the analysis of 10 unpublished oil lamps (fig. 5) displayed at Matrouh Archaeological Museum which are collected from various sources and dated back to the Roman Era.

\section{Methodology of the Study:}

A typological examination is used to place each lamp into its relevant type and chronological periods. The identification used based on parallel examples dated to the same era. Besides, each lamp was digitally photographed from different sides and the potter's stamps were captured, if existed, using a Digital Microscope to document the main details.

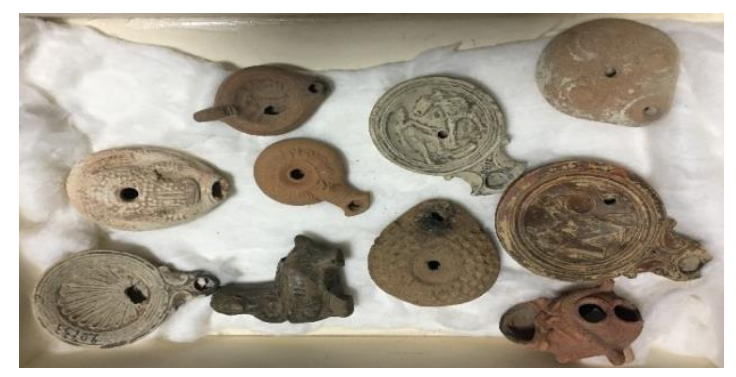

Figure 5: The Objects of the study - (C) Author

\section{Description and Typology:}

The lamps are classified into five groups according to their visible characteristics, shapes, nozzles and fabrics. As will be discussed below, 1 sample represents group 1 - Hellenistic Type. Three samples represent group 2 - Voluted Nozzle Oil Lamps, two samples represent group 3 Plastic figurine Lamp, three samples represent group 4 - Loeschcke Type VIII, one sample represent group 5 - Frog Egyptian Lamp.

\section{Group 1: Hellenistic Type Inventory No: MT403}

\section{Dimensions}

Length: $6.5 \mathrm{~cm}$, with nozzle.

Height: $2 \mathrm{~cm}$.

Width: $7 \mathrm{~cm}$.

Acquired from: Suez Museum, No. 20788.

Materials: Red-brown Nile silt fabric with red core.

Date: late $1^{\text {st }}$ century B.C

\section{Description:}

Mold-made round lamp with egg and dart ornaments (fig. 6). The nozzle is elongated and ended with an eye shaped opening. The central filling hole is surrounded by two 
raised circles. There is an alpha or 'A' sign incised on the bottom. The style of this lamps is parallel to the Hellenistic type from Naukratis and El-Ashmunein 'Neo-Hellenistic' (Bailey, 1975).

Stamp: Impressed Letter Alpha

Bibliography: Unpublished

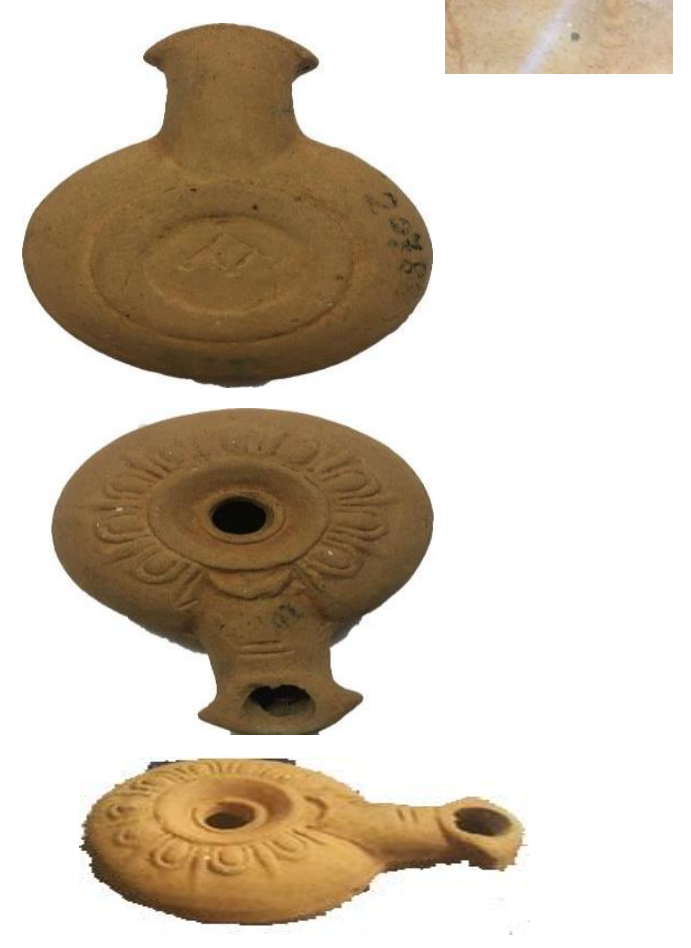

Figure 6: 'Neo-Hellenistic' lamp-MT 403- @ Author

\section{Group 2: Voluted Nozzle Oil Lamps of Loeschcke I, IV:}

According to S. Loeschcke early Roman oil lamps' typology, the first patterns feature volute decorations flanked mainly the nozzle (Loeschcke, 1919). The volute oil lamp models and prototypes were created in Italy and Greece then were spread across the whole Empire (fig. 7) starting from Augustus' period until nearly the $4^{\text {th }}$ century A.D (Bussière, J., \& Wohl, B. L, 2017).

The lamps of Loeschcke type I and IV are quite similar. They are characterized by their usual circular body with concave discus and fairly wide nozzle flanked by two volutes. The major difference is the end of the nozzle. Nozzles in type I (fig. 8) are of three pointed ends, while in type IV they are rounded. The shoulders of the lamp (fig. 9) are almost separated from the discus by number of grooves (Frecer, 2015). The main production of type I began rather earlier than that of Loeschcke type IV. As Frecer stated "the narrower the nozzle the earlier the lamp" (Frecer, 2015).

Three lamps in the museum correspond to such types, one belongs to Loeschcke I (MT 402) and two of Loeschcke IV (MT 400, MT 405), which were largely spread in the $1^{\text {st }}, 2^{\text {nd }}$, $3^{\text {rd }}$ and $4^{\text {th }}$ centuries A.D. They are in a good condition and of very fine quality. The reliefs in miniature on the lamps' disci seem to be executed with incredible skill and attention to detail.

As the shape of the volutes and the width of the triangular nozzle experienced a gradually stylistic change to become wider over time (Frecer, 2015). Loeschcke created three subtypes for his type I (A, B, C) (Table. 1), his classification based on the size and shape of the nozzle and the angle made by two imaginary straight lines joining the volute spines to the nozzle tip angles (fig. 8). Goethert-Polaschek has appropriately added an intermediary nozzle shape $\mathrm{B} / \mathrm{C}$, whose two lines are often nearly parallel (GoethertPolaschek, 1985).

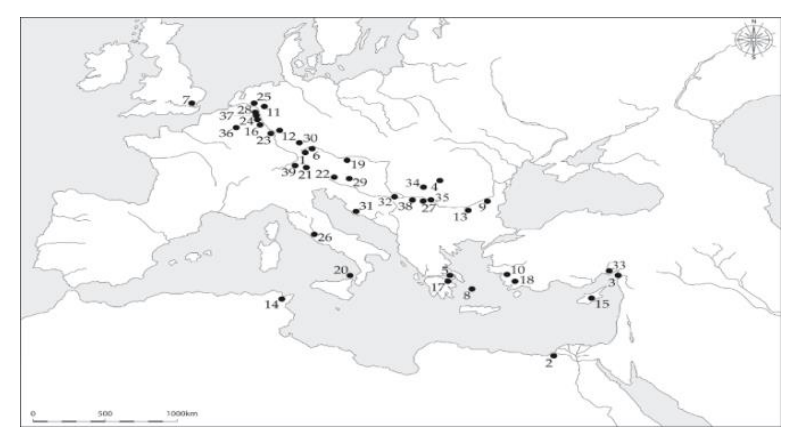

Figure 7: The Loeschcke I oil-lamp types, all three variants. (Korać, 2018) Lamps of that type (type I) were considerably popular, seems to be firstly developed in Italy, in the Early Augustan period, then widespread at all parts of the Roman Empire via either 
export or local imitation and lasted until the end of the Flavian period (Bussière, J., \& Wohl, B. L, 2017).

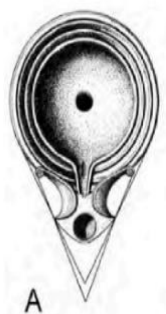

A
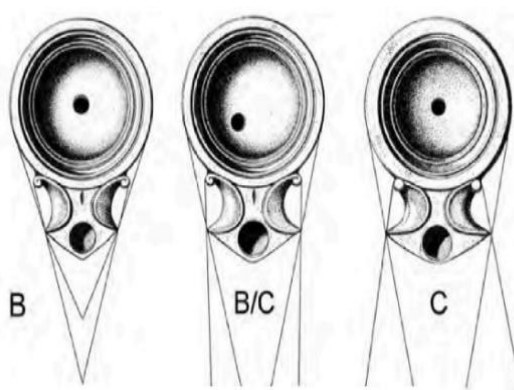

Figure 8: Loeschcke type I nozzle forms divisions, including Goethert-Polaschek variant B/C. source: (Bussière, J., \& Wohl, B. L, 2017, fig.1). Drawing by Jean-Claude Rivel, adapted from Loeschcke 1919, fig. 1, p. 213.

Table 1: nozzle forms divisions of type I, Loeschcke and Goethert-Polaschek. source: by the author depending on (Bussière, J., \& Wohl, B. L, 2017, fig.1).

\begin{tabular}{|c|l|l|}
\hline $\begin{array}{c}\text { LoeschckeType I } \\
\text { Divisions }\end{array}$ & \multicolumn{1}{|c|}{ Characteristics } & Shoulder Forms \\
\hline A & $\begin{array}{l}\text { narrow nozzle and narrow shoulder; } \\
\text { sometimes a shallow V-shaped } \\
\text { channel between the discus and the nozzle }\end{array}$ & I and II \\
\hline B & $\begin{array}{l}\text { the distance between the volute-spines is } \\
\text { larger than the distance between the two } \\
\text { angled sides of the nozzle tip }\end{array}$ & \\
\hline B/C & $\begin{array}{l}\text { the distance between the volute-spines is } \\
\text { equal to the distance between the two angled } \\
\text { sides of the nozzle tip }\end{array}$ & III and IVa \\
\hline C & $\begin{array}{l}\text { the distance between the volute-spines is } \\
\text { smaller than the distance between the two } \\
\text { angled sides of the nozzle tip }\end{array}$ & IVb \\
\hline
\end{tabular}
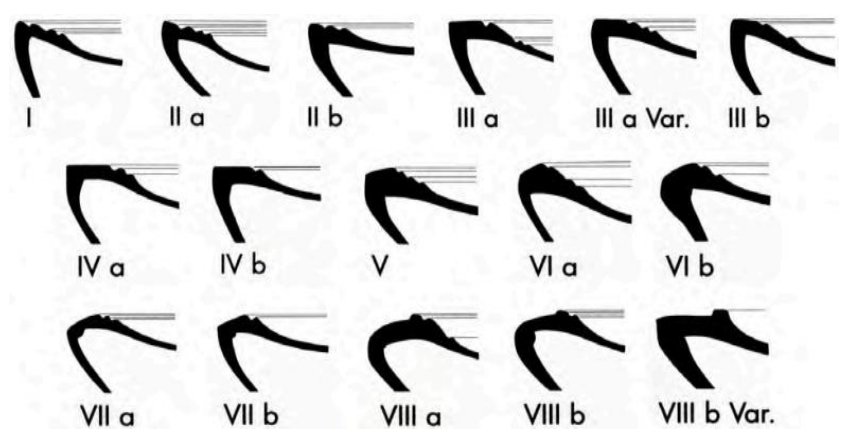

Figure 9: Loeschcke shoulder forms, including Goethert-Polaschek variants. Drawing by Jean-Claude Rivel, adapted from Loeschcke 1919, fig. 2,p. 213

Inventory No: MT 402

\section{Dimensions}

Length: $9.3 \mathrm{~cm}$, with nozzle.
Diameter: $6.5 \mathrm{~cm}$.

Acquired from: Suez Museum, No. 20730.

Materials: Red-brown Nile silt fabric with pale yellow surfaces.

Date: Late first century A.D

Description: Mold-made Roman lamp with voluted angular-tipped nozzle and inwardsloping shoulder with four rills. The tiny filling-hole, at lower part, is lightly centered (fig. 10).

Discus Iconography: Two fighting gladiators. It seems that right gladiator, who is attacking with his raised shield to protect his face, has the upper hand. The other one to the left has dropped his shield and seems to be going to fall before the other one on his knees. By drawing the imaginary lines of Loeschcke on this lamp (fig. 11), it is possible that this lamp belongs to the type I B/C. The distance between the pointed ends is nearly equal to the distance between the volutes

Bibliography: Unpublished

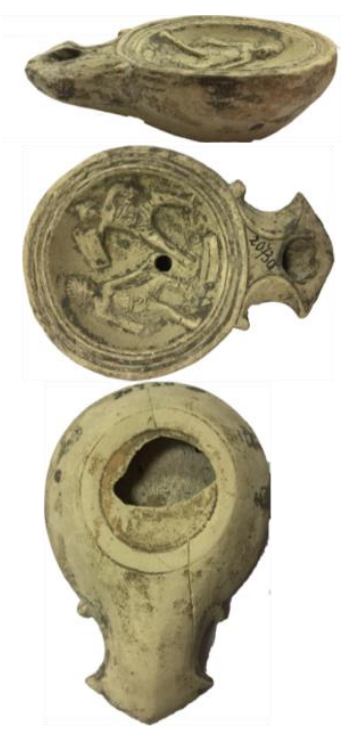

Figure 10: Loeschcke type I LampMT 402- (C) Author

Height: $2.5 \mathrm{~cm}$. 


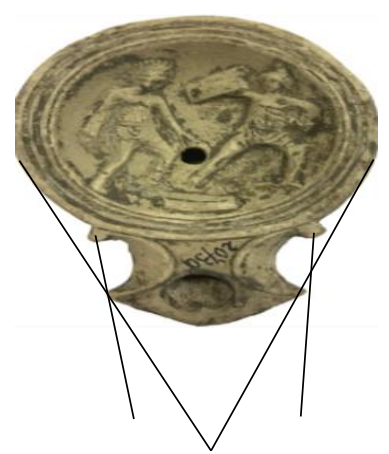

Figure 11: Drawings by the Author to show the type variant $B / C$

\section{Inventory No: MT 400}

\section{Dimensions}

Length: $12 \mathrm{~cm}$, with nozzle.

Height: $2.5 \mathrm{~cm}$.

Diameter: $8.5 \mathrm{~cm}$.

Acquired from: Port Saeid Museum, No. p.3546.

Materials: Red-brown Nile silt fabric.

Date: Late first century A.D to early second century A.D.

\section{Description}

Mold-made Roman lamp. Shoulder: Loeschcke form VIII b. The filling-hole is to the lower right. There is another small air hole on nozzle which is characterized by its roundtipped volute with burn marks. the discus is decorated with a scene of a victorious gladiator (fig. 12).

Gladiator scenes were very popular on Roman style discus lamps across the Roman Empire from c. 30 B.C to 250 A.D. They were also popular in Egypt. They usually show a single gladiator, or a pair fighting.

The base marked by one circular groove with a stamp known as planta pedis. Around 10 A.D, a style of stamps known as planta pedis became common. It's a stamp style in which the names or initials were placed in a footshaped stamp. Notably, no stamps with a footshaped design can be dated before 9 A.D. Furthermore, this type became common by the later reign of Tiberius, therefore, a potter's stamp in planta pedis can be assumed to date after ca. 15 A.D. (Stone, 2015).

Stamp: impressed plain planta pedis

Bibliography: Unpublished
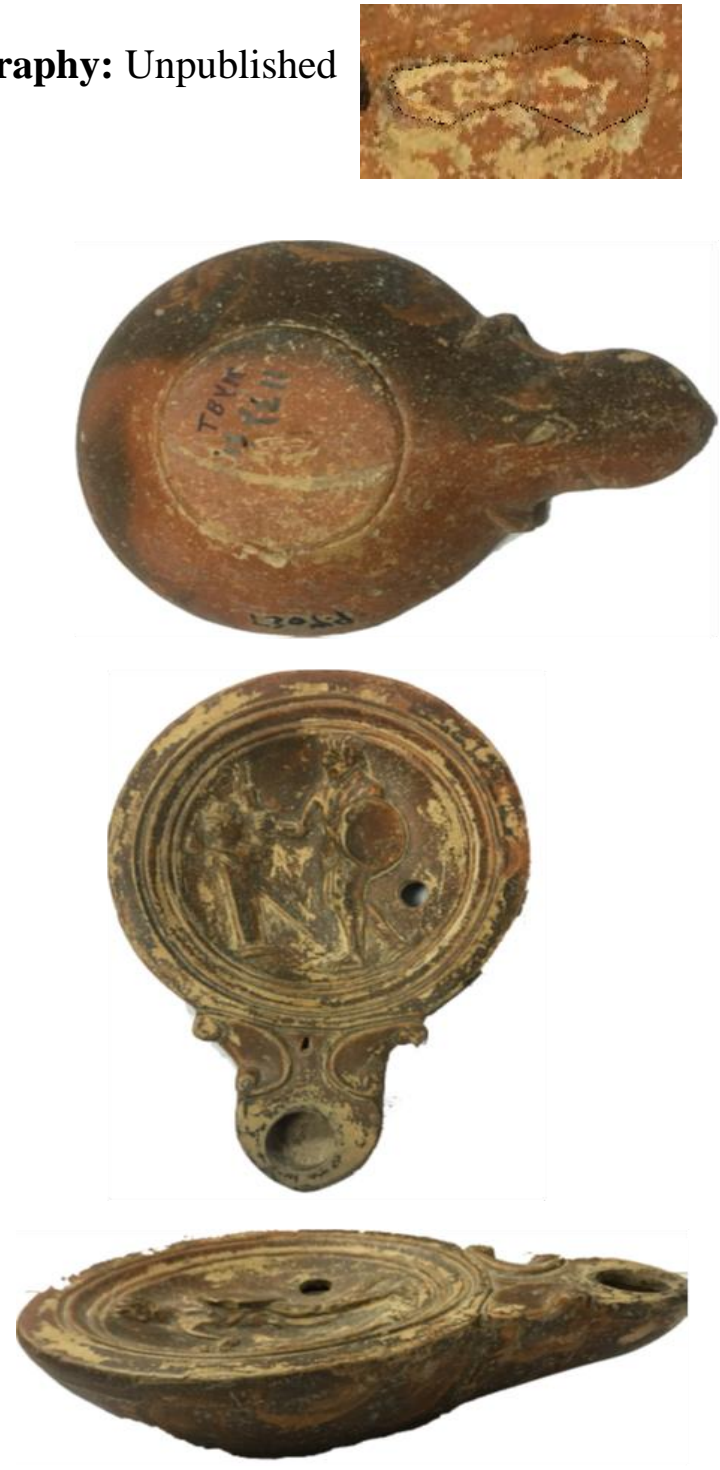

Figure 12: Loeschcke type IV Lamp - MT 400- @ Author 


\section{Inventory No: MT 405}

\section{Dimensions}

Length: $9.7 \mathrm{~cm}$, with nozzle.

Height: $3 \mathrm{~cm}$.

Diameter: $7.5 \mathrm{~cm}$.

Acquired from: Suez Museum, No. 20733.

Materials: Red-brown Nile silt fabric.

Date: Late first century A.D to early second century A.D.

\section{Description}

Mold-made lamp with volute nozzle and round tip with an air hole topped the nozzle. The discus defined by a large scallop shell with 18 ribs. Fill-hole pierced at bottom of shell motif. Slightly raised circular base (fig. 13).

Discus Iconography: Large scalloped shell.

Bibliography: Unpublished

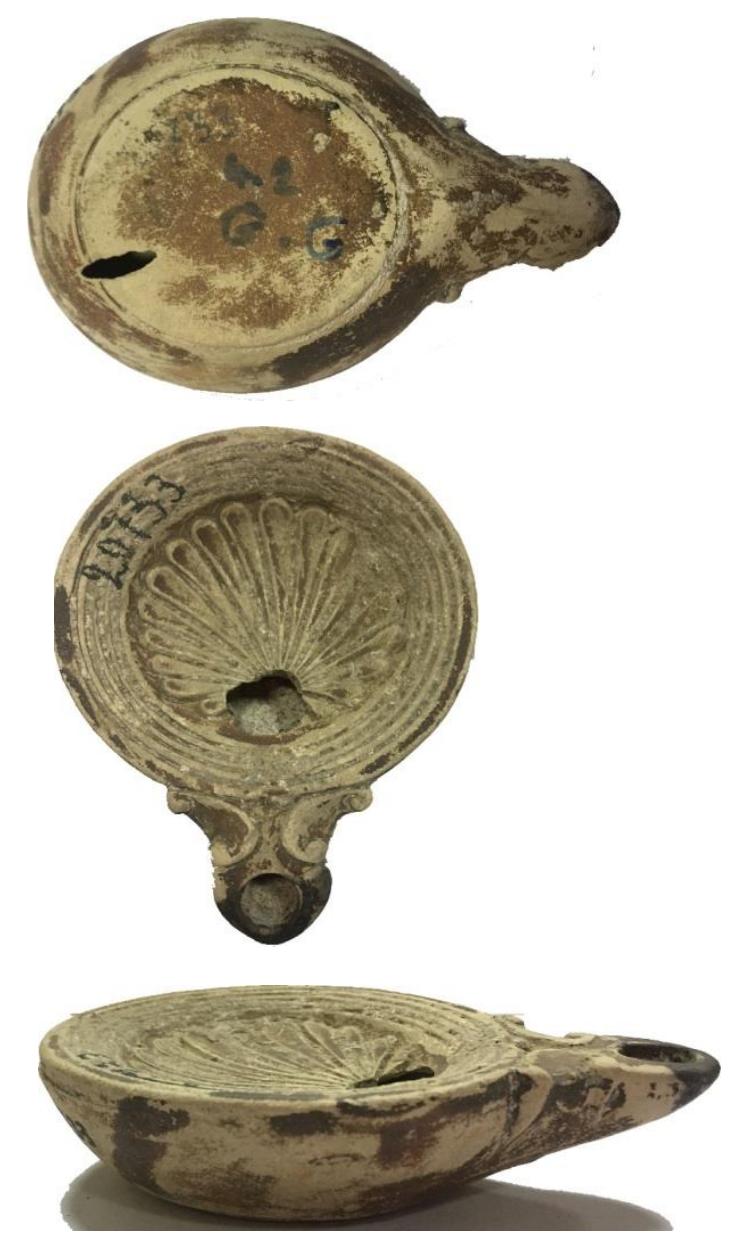

Figure 13: Loeschcke type IV Lamp - MT 405- () Author

\section{Group 3: Plastic Figurine Lamps}

The museum acquires two lamps (MT 401, MT 406), by comparing them with other pieces in other museums collections, it appears that they certainly represent examples of a style known as Plastic lamps. Actually, lamps of that type have their name after their decorative molded shapes (Richter, G. M. 1963).

Plastic lamps with figurines appeared firstly during the Hellenistic period, might have originated in Athens, then they became popular during the $1^{\text {st }}$ and $2^{\text {nd }}$ centuries A.D. Lamps of this type, molded into the shapes of humans, animals, plants, and boats, were found in the Mediterranean basin parts (Richter, G. M. 1963). However, relatively few have been unearthed during excavations, with the remarkable exceptions of Ehnasya in Egypt (Petrie, 1905), at Delos (Bruneau, 1965), and Athens (Grandjouan, 1961). Egyptian and Italian workshops distinguished by being stronger (Bussière, J., \& Wohl, B. L, 2017). With the prevalence of Christian influence within the $4^{\text {th }}$ century, these artifacts decreased. By the end of the $4^{\text {th }}$ century the production line stopped (Richter, G. M. 1963). Grandjouan suggested (Grandjouan 1961) that plastic lamps as cheap objects were the prosperity of the poor. Some were offered as votive offerings in temples, while others were placed in domestic household shrines, known as "lararia"(Cianca, 2018).Others were given to children as toys, put in niches and atop doors to keep away illness or the evil eye, or displayed on shelves as decorative items. Moreover, Grandjouan added that these figures regularly went with their owners to their graves (Grandjouan 1961). 


\section{Inventory No: MT 401}

\section{Dimensions}

Height: $5.5 \mathrm{~cm}$.

Width: $7 \mathrm{~cm}$.

Acquired from: Suez Museum, No. 25727.

Materials: Red-brown Nile silt fabric with red core.

Date: $c$. Second century A.D

\section{Description:}

A fascinating Roman version of the common type terracotta figurine oil lamp (fig. 14). It takes the shape of an African head, rested on three legs, but the features have elements of the grotesque, with bulging, staring eyes, large ears, wide nose and a large open mouth, which is actually a massive wick-hole. The piece is hollow with large two holes, one formed the filling-hole on the forehead and the other one on the back maybe was for the purpose of air passing.

Bibliography: Unpublished

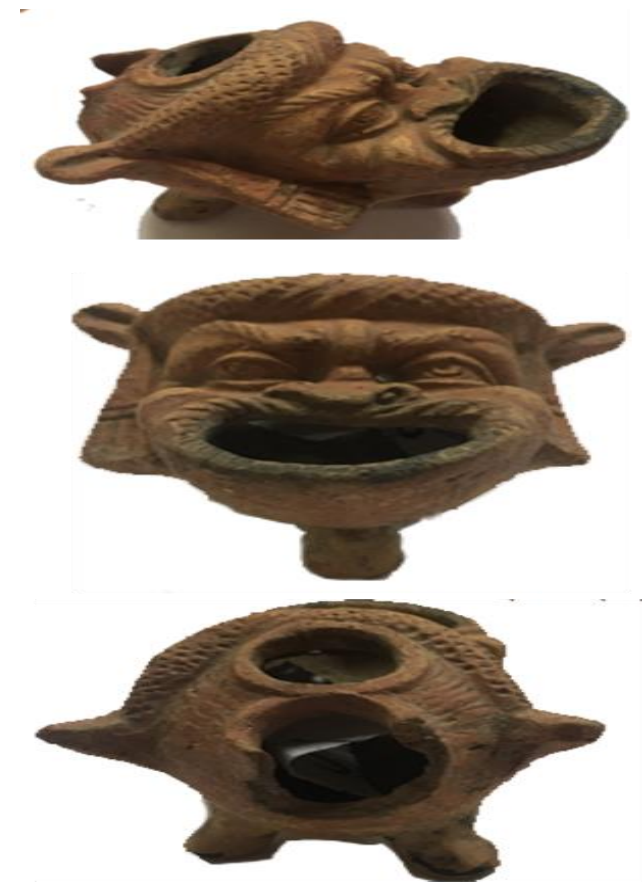

Figure 14: Grotesque Lamp - MT 404 - () Author

\section{Inventory No: MT406}

\section{Dimensions}

Length: $7.5 \mathrm{~cm}$

Height: $8 \mathrm{~cm}$, with handle.

Width: $4.1 \mathrm{~cm}$

Acquired from: Suez Museum, No. 8971.

Materials: Nile silt fabric with grey surfaces.

Date: late $1^{\text {st }}$ century B.C to late $1^{\text {st }}$ century A.D.

\section{Description:}

The body of the lamp takes the ovoidal shape with a large nozzle not projecting beyond the edge; rested on two legs (fig. 15). It is made of dark red-brown clay like that of Naukratis. The handle of the lamp represents a figure of a woman standing against a pillar, at the back of the pillar there is a vent hole topped by the filling hole. By comparing this figurine lamp with other objects, it became clear that it is obviously similar to piece No. 399, PL XI in the Catalogue of the Greek and Roman lamps in the British Museum (fig.16) which represents a bust of Athena. The production of this kind of terracotta lamps in the form of Athena might be presented in Egypt as special offerings at the shrine of the goddess Athena, or more probably was used during the Lamplighting festival of Athena-Neith in Sais. As mentioned above, the celebration of Lamplighting festival was mentioned for the first time by Herodotus during the $5^{\text {th }}$ century B.C., but archeological evidences confirmed that this celebration continued to be held during the Greco Roman period for Athena-Neith (Abdelwahed, 2015).

Bibliography: Unpublished 

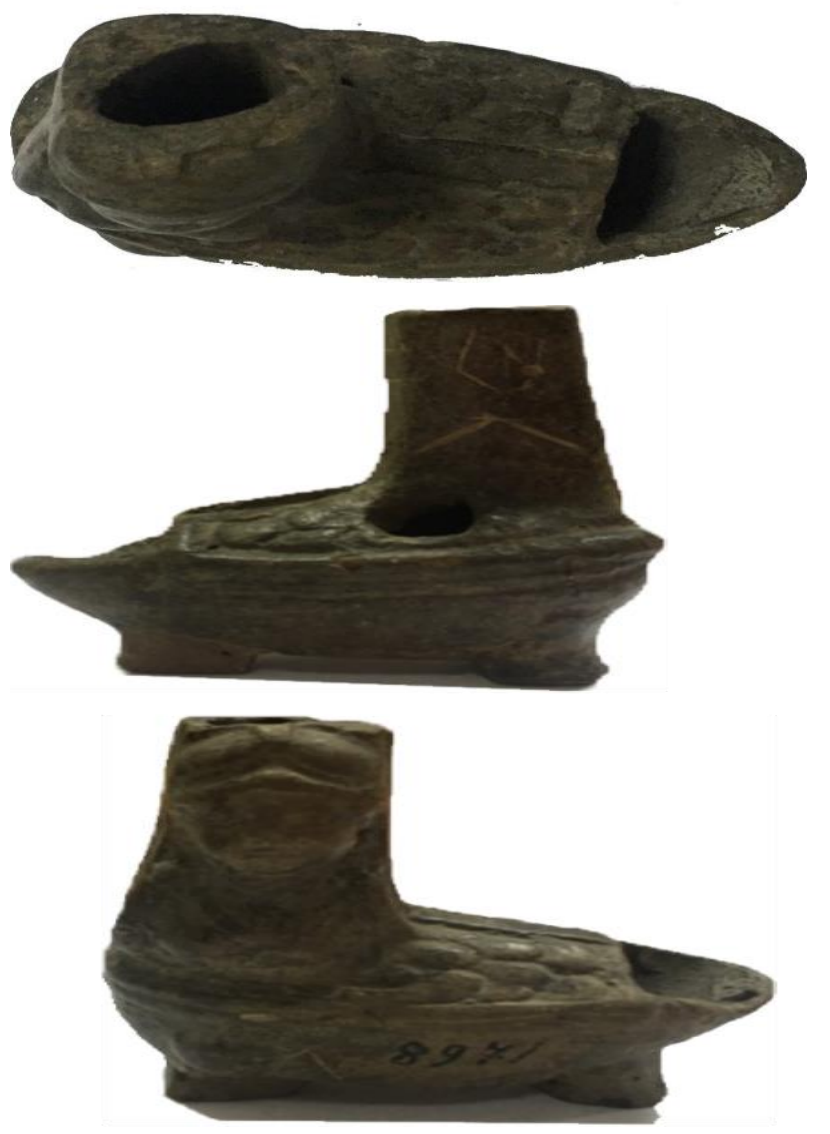

Figure 15: Figurine Lamp - MT 406 - (C) Author

\section{Group 4: Loeschcke Type VIII}

Lamps which are characterized by its circular body with sloping shoulders and distinguished by its very short rounded nozzle, with no volute's motifs, which projects only slightly beyond the body of the lamp is widely known as Loeschcke type VIII. It was classified also by others such as (Bailey O, P, Q; Broneer 25; Deneauve VII and VIII; Dressel 17, 19, 20, 21, 24, 25, 26 and 27; Ivanyi 186; Leibundgut XX, XXI and XXII 187; Ponsich III B and C 188; etc.). lamps with these new nozzles, were not so prone to breakage as the long voluted nozzles of the preceding types, originated mainly in central Italy before the middle of the $1^{\text {st }}$ century A.D following a Hellenistic style (Frecer, 2015), then they quickly became dominant, and flourished throughout the Roman empire, from the end of the $1^{\text {st }}$ till the $3^{\text {rd }}$ century A.D. After that they witnessed an exit as they continued to decrease through the $4^{\text {th }}$ and the $5^{\text {th }}$ centuries (Bussière, J., \& Wohl, B. L, 2017).

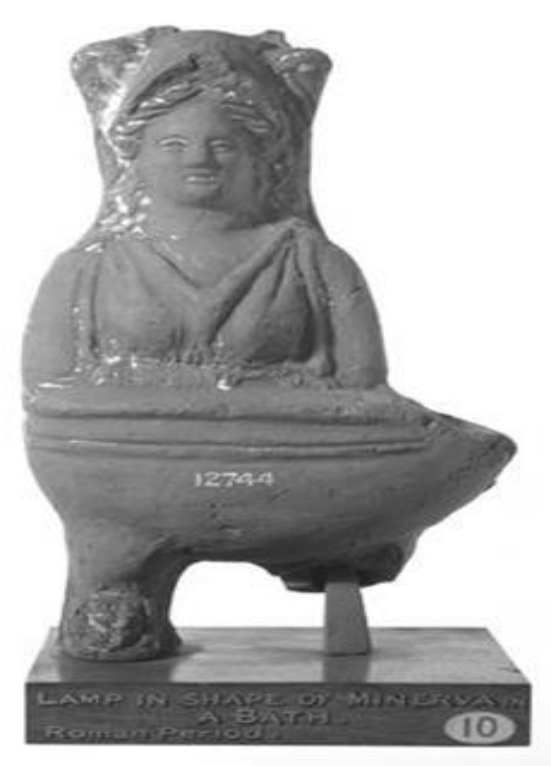

Figure 16: Roman Lamp modeled in the form of Minerva (Athena)- (Walters, 1914, PLATE XI. fig.399)

Three lamps meet the same specifications forms of these short nozzles are among the collections. Two of them can be conclusively identified (MT 398, MT 399), the third one (MT 11) is questioned due to the shape of the discus?

\section{Inventory No: MT 398}

\section{Dimensions}

Length: $8 \mathrm{~cm}$.

Height: $3 \mathrm{~cm}$.

Width: $7 \mathrm{~cm}$.

Acquired from: Saqqara Excavations.

Materials: Marl fabric.

Date: Late first to early third century A.D

Description: Mold-made pottery closed ovalshaped lamp with a small damaged round nozzle, (fig. 17) small, plain and sunken discus with one slightly central filling hole, no 
handles. Shoulder is decorated with four rows of impressed dots; traces of use on the nozzle. The base is stamped by impressed palm leaves.

Stamp: palm leaves

Bibliography: Unpublished

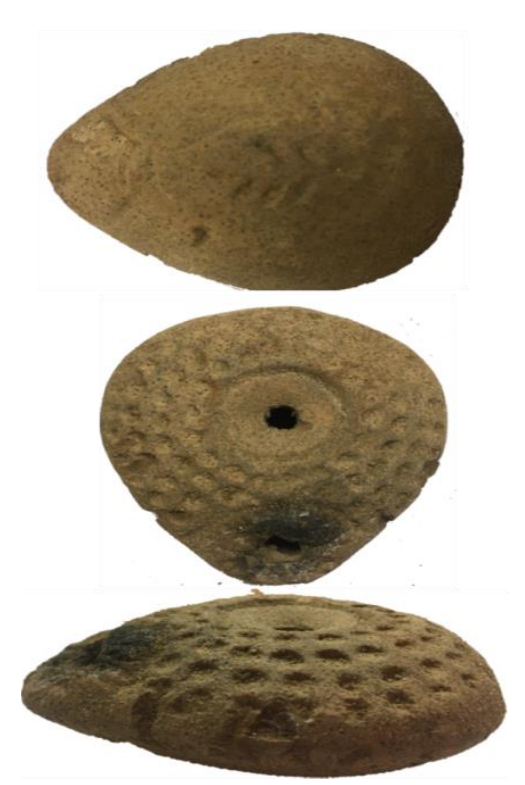

Figure 17: Loeschcke Type VIII - MT 398 - @ A Author

\section{Inventory No: MT 399}

\section{Dimensions}

Length: $7 \mathrm{~cm}$.

Height: $4 \mathrm{~cm}$.

Width: $6 \mathrm{~cm}$.

Acquired from: Saqqara Excavations?

Materials: Marl Fabric.

Date: c. 150-250 A.D?.

Description: Mold-made lamp with round voluted nozzle and central small filling hole. Discus separated from the rounded shoulder by indeterminate raised circular ornaments, perhaps floral motives (fig. 18).

Stamp: Five impressed dots.

Bibliography: Unpublished
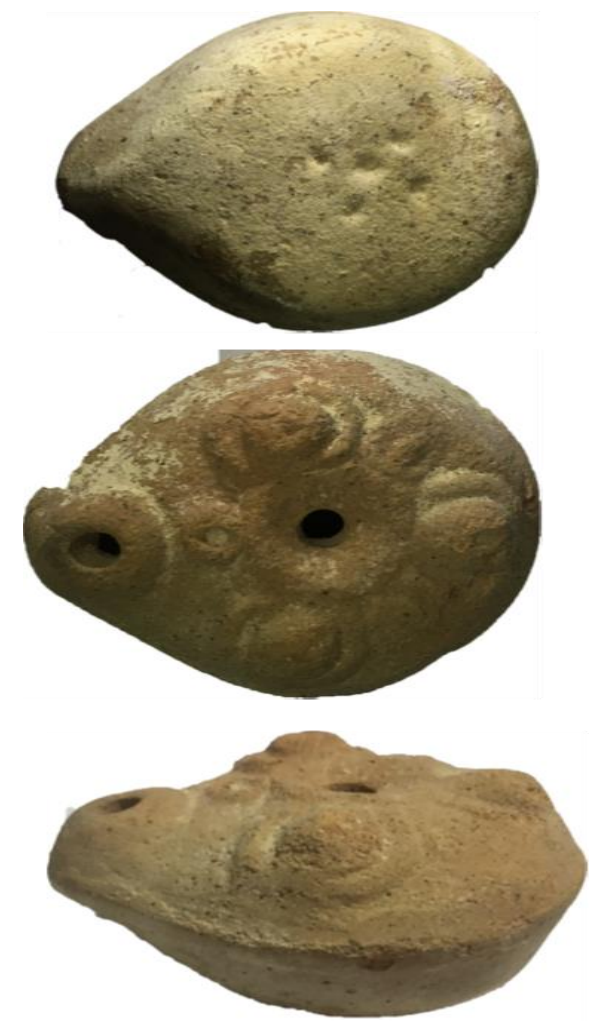

Figure 18: Loeschcke Type VIII-MT 399 - () Author

\section{Inventory No: MT11}

\section{Dimensions}

Length: $7.4 \mathrm{~cm}$, from nozzle to handle.

Height: $2 \mathrm{~cm}$.

Width: $5 \mathrm{~cm}$.

Acquired from: Graeco-Roman Museum, Alexandria.

Materials: Red-brown Nile silt fabric with red core.

Production date: $150-250$ A.D?.

\section{Description:}

Mold-made oil lamp with an elongated body, a plain rim and a closed handle. The discus is decorated with reliefs depicting goddess Aphrodite and traces of her shell (fig. 19). The circular flat base is decorated with an 
impressed palmette flanked by two motifs in the shape of a tilted letter S, probably the maker's mark. By comparing it to object no. H2756 in the British Museum from Naukratis, it seems that this piece is dated back to first century A.D.

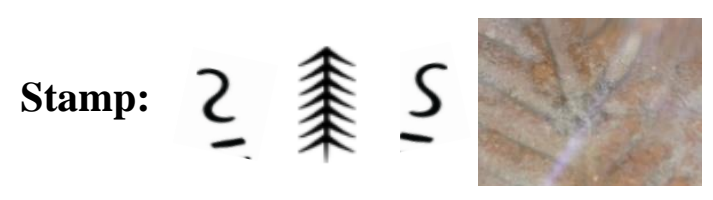

Bibliography: Unpublished

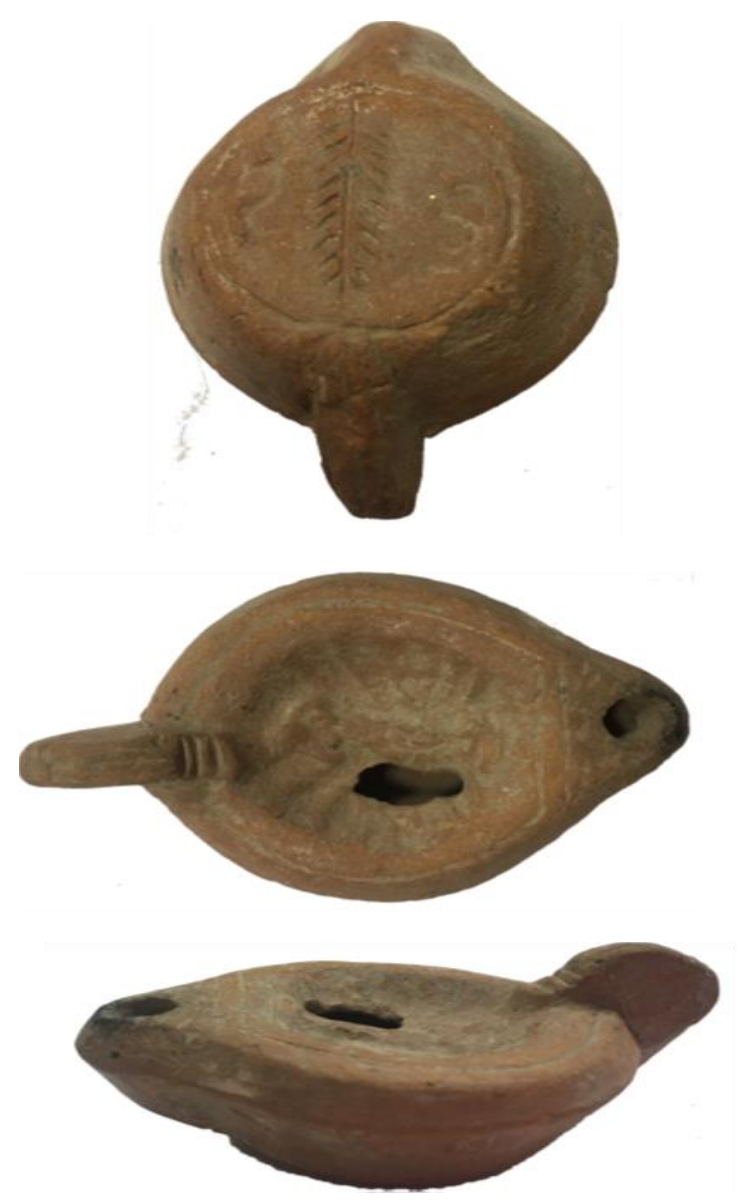

Figure 19: Loeschcke Type VIII? - MT 11 - @ Author

\section{Group 5: Frog lamps:}

Egyptian Frog lamps have been produced solely in Egypt and were popular for a long time. They get their name from the frog motif that often appears in relief on the upper portion of the lamp (PawlikowskaGwiazda, 2019).
For the ancient Egyptians, the frog was sacred and its cult was one of the oldest in Egypt. It was the symbol of rebirth and resurrection. According to its life cycle, it is a type of transformation, from an egg to a tadpole to a frog. Hence, the frog was connected with the ancient Egyptian mythologies of creation, and resembled transformation from chaos to existence and order. The frog, as symbol of rebirth, appeared since the Predynastic Period in amulets. During the Dynastic Period it was identified with Heket, goddess of birth and fertility who was worshiped in the form of a frog (Shaw, I., \& Nicholson, P. T., 2008). It was connected with other gods such as; god Ptah (Massey, G. 1907), Nile-God Hapi (Lurker, M., 1980), Atum-Re and Amun. Due to its sacred characteristics, it was easy to be adapted by the Coptic art as a Coptic symbol of rebirth and resurrection (Shaw, I., \& Nicholson, P. T., 2008).

Lamp's production fashioned in the shape of a frog or containing froglike decorative elements were common over a longer period of time. Bussière \& Wohl, depending on excavations evidences, stated that this type might have been in production since the beginning of the $2^{\text {nd }}$ century A.D, it most likely continued through the $3^{\text {rd }}$ and $4^{\text {th }}$ centuries (Bussière, J., \& Wohl, B. L, 2017). However, Bailey mentioned later versions of the $5^{\text {th }}, 6^{\text {th }}$, and $7^{\text {th }}$ centuries A.D. (Bailey, D. M. 1975). Generally, shapes and forms of that type varied but its base is generally flat. The base may endure various potters' marks like the shape of the letter alpha (Rosenthal, R., \& Sivan, R. 1978). Among the museum collections there is a very interesting lamp belongs to the identical Egyptian "frog type" lamp (MT 404) see below. 


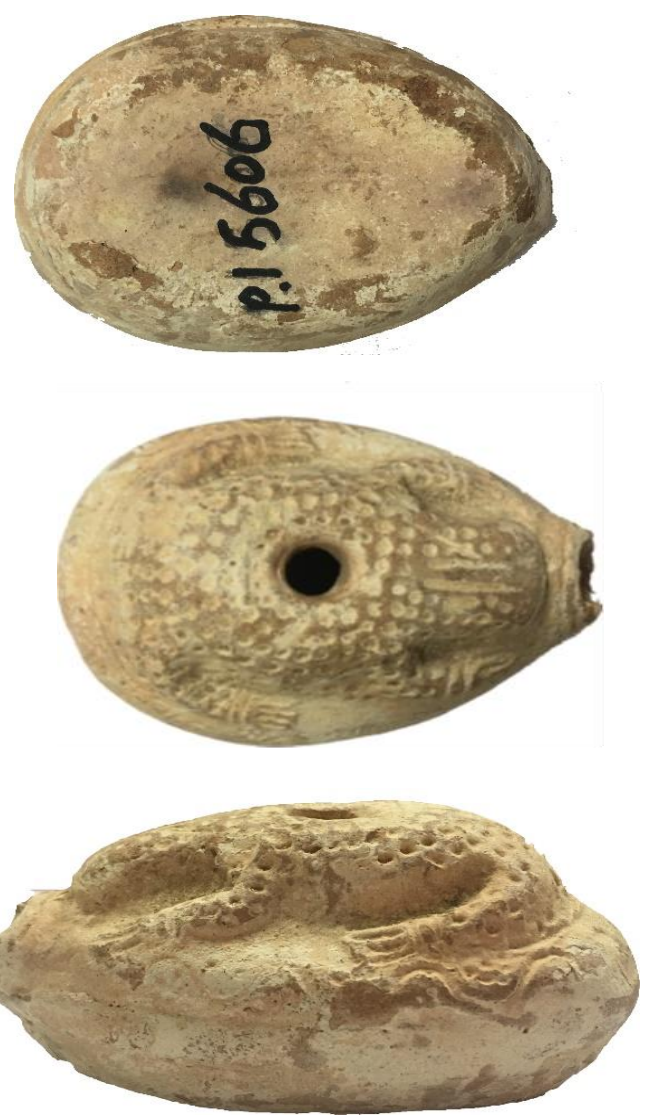

Figure 20: Frog Lamp-MT 404 - (C) Author

\section{Inventory No: MT404}

\section{Dimensions}

Length: $9.5 \mathrm{~cm}$.

Height: $4.5 \mathrm{~cm}$.

Width: $6 \mathrm{~cm}$.

Acquired from: Suez Museum, No. 15606.

Materials: Pale yellow marl fabric.

Date: c. $150-400$ A.D

\section{Description}

Mold-made white Egyptian 'frog lamp' (fig. 20). It has a natural representation of a full frog on the upper side that forward facing head pointing towards the front nozzle. Almost egg-shaped with small filling hole in the center.

Bibliography: Unpublished

\section{Findings:}

The assemblage consists of ten lamps most of them in good condition; they are mold-made, of different closed-shape body type, most of them with decorated discuses, and a disc base or a ring base sometimes defined by a grooved stamp (MT11, MT 398, MT 399, MT 400 and MT403). Mainly, most of the lamps have no handles except (MT 11), which has small projected handle at the rear and (MT 406) that has a figurine handle.

Three discuses are concave with circular borders, two decorated with projected gladiators' scenes (MT 400, MT 402) and the other with a shell (MT 405), according to the nozzle shape they are classified as Loeschcke I and IV oil-lamp types. Two of them represent figurines and belong to a common type spread in the Roman Empire known as plastic lamps (MT 401, MT 406). Only one within the collections belongs to a type produced exclusively in Egypt which is the Frog Lamp (MT404). The other lamps show raised decorated motives (MT 399), eggs and darts (MT 403), circle decorations on the lamp shoulders (MT 398) and Aphrodite on the discus (MT 11). Depending on the shape of the body and nozzle, those later lamps, excluding the Hellenistic one (MT 403), could be classified under Loeschcke type VIII. In the studied assemblage, seven lamps are made of red-brown Nile silt, the other three (MT 398, MT 399 and MT 404) are made of Marl fabrics. Other findings can be summarized as follow:

- Theses lamps are distinguished by their different shapes as well as the subjects depicted on them.

- They are all made from the local Egyptian Clay.

- These lamps are mostly produced by the school of Alexandria, one of them of pure Egyptian production, and the 
others imitating those spread in the Roman Empire.

- All of them are Mold-Made.

- The subjects depicted varied, as well as the decorations, whether they were plants, humans or geometrics.

- It is noticeable that the markings and stamps on this collection were various, but all are in impressed reliefs.

\section{Conclusions:}

This study provides a scientific preservation and archaeological publication of unpublished terracotta oil lamps collected from different Egyptian museums and now exhibited in Matrouh Archaeological Museum. They, unfortunately, are neither identified nor dated precisely, therefore the investigation aims to determine their artistic pattern, type and chronology. Based on the typological examination the sample was divided into five groups according to their visible characteristics, shapes, nozzles and fabrics. The identification also based on comparing the lamps with parallel examples exhibited in other museums, especially those of the British Museum.

The study revealed that most of them dated back to the late $1^{\text {st }}$ century B.C till the late third century A.D. It also documents and fully describes each object as well as recording and identifying, using digital techniques, the existed stamps. Therefore, the museum and its visitors can contribute from the study results as well as specialists in the fields of GraecoRoman archeology.

\section{Acknowledgements:}

The author expresses her sincere gratitude to $\mathrm{Mr}$. Saad Haredy the manager of Matrouh Archeological Museum and Miss. Samar Sedeq for their support and helpful insights. Further thanks to Dr. Osama Basiouny, director of the Permanent Committee for Islamic and Coptic
Antiquities for his help in getting the permissions to study and publish the sample.

\section{References:}

- Abdelwahed, Y. (2015). The Illumination of Lamps (Lychnokaia) for Neith in Sais/Esna in Greco-Roman Egypt. Abgadiyat. 10. 31-45. 10.1163/22138609-90000055.

- art, P. (2020). Lighting. Retrieved 30 May 2020, from https://archeologie.culture.fr/lascaux/en/lightin g

- Bailey, D. M. (1975). A Catalogue of the Lamps in the British Museum: Bailey, DM Roman lamps made in Italy. British Museum Publications Ltd..

- BARTOLI, P. \& BELlORI, G.P. (1691). Le antiche Lucerne sepolcri figurate, raccolte dale cave sotterranee. Rome.

- Beaune, S., White R., 1993: Ice Age Lamps Scientific American, March 1993.

- Bogucki, P. I. (2008). Encyclopedia of society and culture in the ancient world. Facts On File.

- Bruneau, P. (1965). Exploration archéologique de Délos: faite par l'Écolefrançaised'Athènes. Les lampes/par Philippe Bruneau. Fascicule XXVI. Ecole françaised'Athènes.

- Bussière, J., \& Wohl, B. L. (2017). Ancient Lamps in the J. Paul Getty Museum. Los Angeles: J. Paul Getty Museum.

- Chambers, W., \& Chambers, R. (1891). Chambers' Encyclopadia: A Dictionary of Universal Knowledge (Vol. 8). W. \& R. Chambers.

- Cianca, J. (2018). Sacred Ritual, Profane Space: The Roman House as Early Christian Meeting Place (Volume 1) (Studies in Christianity and Judaism Series) (3rd ed.). McGill-Queen's University Press.

- De Rosa, K. (2015). Roman and late antique ceramic oil lamps in the Museum of Ancient Cultures: a typological and compositional analysis. 
- $\quad$ Fitch, C. R., \& Goldman, N. (1994). Cosa, the lamps (Vol. 39). University of Michigan Press.

- Forbes, R. J. (1965). Studies in ancient technology. 5 (Vol. 2). Brill Archive.

- Forbes, R.J. 1966. Studies in Ancient Technology, Leiden pages $146 \mathrm{ff}$.

- Frecer, R. (2015). Gerulata: The Lamps. Charles University in Prague, Karolinum Press.

- Goethert-Polaschek, K. (1985). Katalog der römischenLampen des

RheinischenLandesmuseums Trier. P. von Zabern.

- Grandjouan, C. (1961). Terracottas and plastic lamps of the Roman period (Vol. 6). American School of Classical Studies.

- Knowles K. (2006). The Pottery Lamps. In V. A. Maxfield/D.P.S. Peacock (eds.), Survey and excavations. Mons Claudianus: 19871993. Volume III, ceramic vessels and related objects (Le Caire: IFAO), 309-426

- Korać, M. (2018). Oil-Lamps from Viminacium (Moesia Superior), Institute of Archaeology, Belgrade.

- Lapp, E., \&Nicoli, J. (2014). Exploring 3D modeling, fingerprint extraction, and other scanning applications for ancient clay oil lamps. Digital Applications in Archaeology and Cultural Heritage, 1(2), 34-44.

- Lapp, E.C., 2004. Clay lamps shed new light on daily life in antiquity. Near East.Archaeol. 67 (3), 174-175.

- Lurker, M. (1980). The gods and symbols of ancient Egypt: An illustrated dictionary. Thames and Hudson.

- Massey, G. (1907). Ancient Egypt: The Light of the World (12 volumes in 1) (Vol. 1). Lulu. com.

- Mazurek, A. (2013). Light My Fire: An Overview, Typology, and Analysis of Erotic Roman Lamps.

- Mond, R. and Myers, O.H. 1934. The Bucheum, London, 89, 135.

- $\quad$ Murray, M. A. 1949. The Splendour that was Egypt, New York.
- O'Rorke, M. (2010). Clay, light \& water. A\&C Black.

- Pawlikowska-Gwiazda, A. (2019). Terracotta oil-lamps from Egypt's Theban region in the collection of the Metropolitan Museum of Arts, New York. Polish Archaeology in the Mediterranean, 28, 641-657.

- Petrie, W. M. F. (1905). Roman Ehnasya (Herakleopolis Magna), 1904: Plates and Text Supplementary to Ehnasya(No. 26). Egypt exploration fund.

- Richter, G. M. (1963). The Athenian Agora, VI. Terracottas and Plastic Lamps of the Roman Period.

- Rosenthal, R., \& Sivan, R. (1978). Ancient lamps in the Schloessinger Collection (Vol. 8). Institute of Archaeology, Hebrew University of Jerusalem.

- $\quad$ Serpico, M. and White, R. 2000. Oil, fat and wax. In Nicholson, P.T. and Shaw, I. Ancient Egyptian Materials and Technology, Cambridge, 390-429.

- Shaw, I., \& Nicholson, P. T. (2008). The British Museum Dictionary of Ancient Egypt. British Museum Press.

- Sindh Exploration and Adventurer Society. (2001). The Archaeological Review (Vols. 8$10)$.

- $\quad$ Smith, R.H. 1964, The Household Lamps of Palestine in Old Testament Times In The Biblical Archaeologist, 27, 2-31.

- Stone Lamps of the Palaeolithic. (2020). Retrieved 5 July 2020, from https://www.donsmaps.com/lascauxlamp.html \#reference

- Stone, S. C. (2015). Morgantina Studies, Volume VI: the hellenistic and roman fine pottery. Princeton University Press.

- Thomas, R. (2013). Lamps in terracotta and bronze. Villing, A., Bergeron, M., Bourogiannis, G., Johnston, A., Leclère, F., Masson, A., Thomas, R. Naukratis: Greeks in Egypt. British Museum Online Research Catalogue. URL: http://www. britishmuseum. org/naukratis. 
- Twomey, T. (2013). The cognitive implications of controlled fire use by early humans. Cambridge Archaeological Journal, 23(1), 113-128.

- Walters, H. B. (1914). Greek and Roman Lamps in the British Museum.

- Westenholtz, J. G. (Ed). (2004). Let there be light: Oil lamps from the Holy Land. Jerusalem: Bible Lands Museum. 